\title{
Municipal Solid Waste Management Practices in Alwar, Rajasthan, India
}

\author{
Arun Kumar Yadav, Mahendra Pratap Choudhary
}

\begin{abstract}
Solid waste management is the process of collecting, treating and disposing off the material after segregating the reusable and recyclable material. After observing mismanagement of municipal solid waste in Alwar city, it was decided to carry out a study to find out the status of the solid waste management practices. During study, the residential areas of the city were visited and sample were collected from households on per day basis, which helped to analyze the waste generation as well as the seasonal variation of the waste. It has been observed that all wastes are mixed together by the residents due to unawareness about the biodegradable and non-biodegradable wastes. Even, it is very difficult for the concerned authorities in municipal corporation Alwar to estimate the actual quantity of biodegradable and non-biodegradable wastes. In absence of segregation of these wastes, the authorities normally use thumb rules for estimating the dry and wet wastes. During study, the main thrust was given to find out the variation in seasonal waste in different areas of the city, so as to help in assessing the deployment of available resources for their full utilization. The biodegradable waste may be used for vermi-composting as well as generation of bio-gas also. It was observed that segregation is not done at the level of individual households and therefore, awareness among people is to be brought as well as to deploy additional manpower for segregation at the collection points. There is a dire need for engaging sufficient number of manpower by the municipal corporation Alwar for collection and transportation of solid waste in the city. At present, diesel vehicles are used for transportation, so it is suggested to make use of electric vehicles like rickshaws and loaders for environmental protection and sustainable development.
\end{abstract}

Keywords: Bio-degradable and Non-biodegradable waste, Solid Waste, Seasonal Variation, Vermi-compost.

\section{INTRODUCTION}

Today, we are facing a very serious problem of management of waste generation from the households. The Govt. of India is allocating huge amounts of budget for cleanliness in the country. On an average, an Indian person generates $0.5 \mathrm{~kg} /$ day waste, which is quite a very big quantity to handle such wastes with increasing population. If scientifically utilized, this waste can be used for composting and bio-gas generation

Revised Manuscript Received on February 05, 2020.

* Correspondence Author

Arun Kumar Yadav, M. Tech., Department of Civil Engineering, Rajasthan Technical University, Kota, Rajasthan, India.

E-mail: yakyadav16@gmail.com

*Dr. Mahendra Pratap Choudhary, Associate Professor, Department of Civil Engineering, Rajasthan Technical University, Kota, Rajasthan, India. E-mail: choudhary mp@yahoo.co.in

(C) The Authors. Published by Blue Eyes Intelligence Engineering and Sciences Publication (BEIESP). This is an open access article under the CC BY-NC-ND license (http://creativecommons.org/licenses/by-nc-nd/4.0/) which will help in providing employment and revenue generation. Solid waste is produced by people in different forms and it is increasing with the growing population. Management and proper handling of the solid waste is one of the most neglected aspects in our country. Solid wastes are probably the most visible forms of pollution which have their impact on soil and groundwater. People throw away millions of tonnes of solid waste every year. Proper collection and disposal of such solid wastes is very important for the overall health of urban citizens as it at times, contains toxic substances. Indian cities generate about 85,000 tonnes per day of solid waste. None of the cities in India collects and disposes its solid waste in a safe way rather than Mysuru, Karnataka. The solid waste generated by some of the industries, especially those pertaining to metals, chemicals, leather, paper, dying and rubber contains toxic elements like mercury, cyanide, arsenic etc. and carcinogenic substances. In absence of proper treatment, most of the solid waste is either thrown on roadsides or can be seen floating in ponds, lakes and streams. While the existing dumps aren't being cleared and the country is short of landfill sites; more and more solid waste that is difficult to dispose off, is being produced. About 50-60\% of India's solid waste comprises of bio-degradable organic waste originating from kitchens and markets. This solid waste can be disposed off through the process of composting. Incineration of some of the solid waste is another alternative available. Paper and cardboard packing that decays or can be recycled to save trees and may be replaced by plastic that do not decay and give off harmful gases when burnt. According to an estimate the total urban municipal solid waste generated in our country will increase by six times in the coming 50 years.

\section{A. Study Area}

The Area of present study lies in the municipal corporation limits of Alwar city, the gateway of Rajasthan. Alwar district lies in the north-east of the state. It is situated at $27^{\circ} 34^{\prime \prime}$ to $27^{\circ} 57^{\prime \prime}$ north latitude and $76^{\circ} 07^{\prime \prime}$ to $77^{\circ} 13$ " east longitude and spreads over an area of $8380 \mathrm{sq}$. km. The city area is $110 \mathrm{sq}$. $\mathrm{km}$ constituting $1.30 \%$ of the total area of the district. The district headquarter Alwar has a population of 322,568 as per 2011 census and present population is about 3.70 lakh.

\section{B. Aim of Study}

Alwar city is one of the major industrial hubs in Rajasthan and due to increase in population density; management of solid waste is one of the big problems. The solid waste management (SWM) basically has three main components known as collection, transportation and disposal. The goal of SWM is to reduce the quantity of solid waste disposal on land by making recovery of reusable and recyclable materials and getting resources in the form of energy from solid waste in a way which is both 
environment-friendly as well as cost effective. As the cost of land in increasing rapidly, the landfill option of treatment becomes expensive.

The basic aim of the present study is to calculate the MSW generation per day from the city, seasonal variation in it and to analyze the composition of the collected MSW.

\section{RELATED WORK}

Solid waste comprises of countless different materials like dust, food wastes, packing in form of paper, metals, plastics, glass, discarded cloth furnishing, garden waste as well as hazardous and radioactive wastes. Solid waste has three main characteristics of weight generated, density and constituents. These characteristics of solid waste vary from country to country, town to town and place to place depending upon types of sources of solid waste whether it is domestic waste or industrial waste or solid waste from commercial areas. The following table I shows composition of solid wastes in some major Indian cities.

Table I: Compositions of Solid Wastes in Indian Cities [1]

\begin{tabular}{|c|c|c|c|c|c|c|}
\hline \multirow[t]{3}{*}{ Cities } & \multicolumn{6}{|c|}{ Composition of Solid Waste (\%) } \\
\hline & \multicolumn{5}{|c|}{ Non-bio degradable Waste } & \multirow{2}{*}{$\begin{array}{c}\text { Bio- } \\
\text { degrad } \\
\text { ab-le } \\
\text { Waste }\end{array}$} \\
\hline & $\begin{array}{c}\text { Others } \\
*\end{array}$ & $\begin{array}{c}\text { Plasti } \\
\text { C }\end{array}$ & $\begin{array}{c}\mathrm{Me} \\
\text { tal }\end{array}$ & $\begin{array}{l}\text { Gla } \\
\text { ss }\end{array}$ & $\begin{array}{c}\text { Ash } \\
\& \\
\text { earth }\end{array}$ & \\
\hline Calcutta & 3.18 & 0.65 & $\begin{array}{c}0.6 \\
6\end{array}$ & $\begin{array}{c}0.3 \\
8\end{array}$ & 34.00 & 47.00 \\
\hline Delhi & 6.29 & 0.85 & $\begin{array}{c}1.2 \\
1\end{array}$ & $\begin{array}{c}0.5 \\
7\end{array}$ & 36.00 & 35.00 \\
\hline Nagpur & 1.88 & 1.35 & $\begin{array}{c}1.3 \\
3\end{array}$ & $\begin{array}{c}1.3 \\
4\end{array}$ & 41.42 & 34.81 \\
\hline $\begin{array}{l}\text { Bangalo } \\
\text { re }\end{array}$ & 4.00 & 2.00 & - & $\begin{array}{c}1.0 \\
0\end{array}$ & 15.00 & 78.00 \\
\hline Mumbai & 10.00 & 2.00 & $\begin{array}{c}3.6 \\
0\end{array}$ & $\begin{array}{c}0.2 \\
0\end{array}$ & 44.20 & 40.00 \\
\hline
\end{tabular}

*Others include e-waste, cans, thermo-coal, sanitary pads \& synthetic fibres

To address the issues related with management of solid waste, the Ministry of Environment, Forest and Climate Change, Govt. of India has implemented the Solid Waste Management Rules, 2016 [2].

In developed countries, these days, waste is not considered as waste. It is considered as a useful resource because it has the potential to be converted to energy. In waste to energy plants, municipal solid waste comprising garbage, trash, plastic, paper, cardboard, wood etc. is often burnt to produce steam in a boiler that is used to generate electric power. There are different types of waste to energy technologies like composting [3-4], direct combustion (mass burn and RDF i.e. Refuse Derived Fuel) [5], pyrolysis [6-7], conventional gasification [8] and plasma arc gasification [9] having their own advantages and disadvantages. Many researchers have worked out the economic benefits of harnessing solid waste in their studies [10-11].

\section{METHODOLOGY}

For conducting comprehensive study of solid waste management and potential vermin-composting of biodegradable waste, various instruments were used for experimentation and observation work. The samples were collected from the various locations of the city for analyzing the different characteristics of the municipal solid waste.

\section{A. Instrumentation}

The following instruments were used during study period.

1. Mechanical spring weighing machines of $100 \mathrm{~g}$, $1000 \mathrm{~g}$ and $10 \mathrm{~kg}$

2. Digital weighing machine up to $20 \mathrm{~kg}$

The process used for experimentation and observation of the research analysis, consisted of the following:

(i) Door to door collection of municipal waste from the residential area

(ii) Weight measurement of the waste generated from each household

(iii) Segregation of the waste and weighing of the each component

\section{B. Division of City into Zones}

For the purpose of study, the area of Alwar city was divided into four zones comprising all types of areas like residential, institutional, commercial and industrial. The study has been conducted in the municipal corporation limits of Alwar city for a period of more than one year during May-2018 to May-2019. The following figure 1 shows zone-wise distribution of study area.

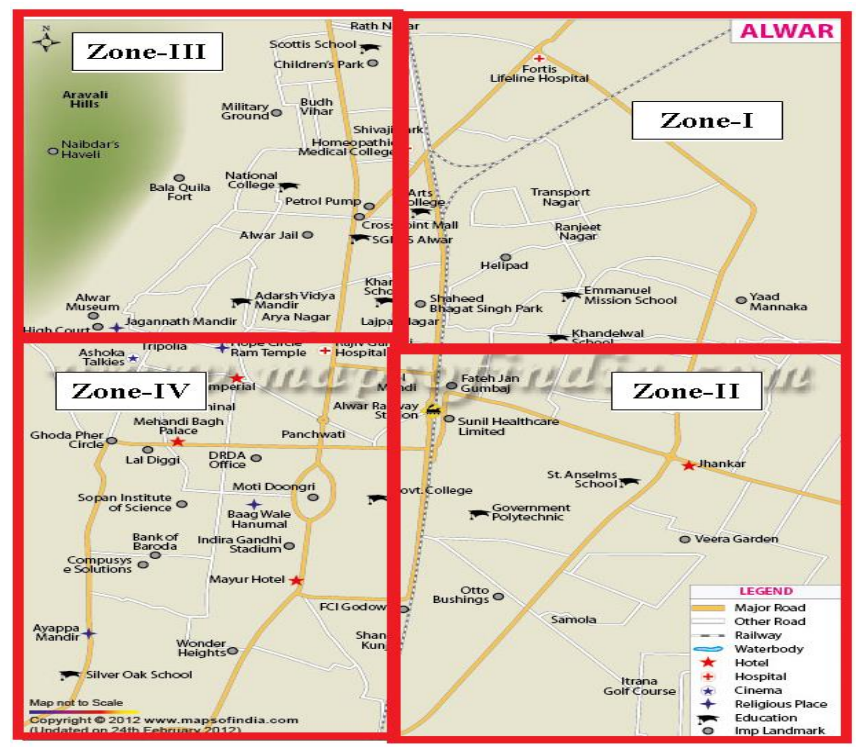

Figure 1: Zone-wise study area of Alwar city

\section{Estimation Municipal Solid Waste}

The mean solid waste generation per capita per day in residential areas (households) of Alwar city was calculated by taking thirty samples of solid waste from each zone in a period of three months for one year of study period. During each sampling, the solid waste generated during twenty four hours in a household was collected in a polythene bag of capacity $10 \mathrm{~kg}$ and weighed. The total number of residents of each household during sampling period was also recorded to calculate per capita per day generation. Weighing of solid waste was done with the help of digital balance and $100 \mathrm{~g}$, $1000 \mathrm{~g}$ and $10 \mathrm{~kg}$ spring balances. Solid waste generation (kg/capita/day) was calculated by dividing the solid waste generation/day in a particular household during 24 hours by the total number of residents of that household during sampling.

Published By: 
The qualitative and quantitative composition of biodegradable, non-biodegradable wastes were also calculated by analyzing the per day solid waste generation of each household.

Data from each household regarding the separation of various wastes like paper ware (books, note-books, newspapers, magazines); plastic ware (containers, buckets, bottles, plastic woven sack, scrap); metallic ware (tin containers, scrap); glassware (beer and wine bottles, other bottles); cardboard (craft, sweep); jute (jute woven sack); to be sold to Itinerant Waste Buyers (IWB) or waste dealers at weekly or monthly intervals were also recorded to calculate average segregation of solid waste (kg per capita per day of recycled or reused waste) at each household.

Data of all zones in a particular three months period was compiled to calculate mean gross solid waste generation, solid waste segregation and net solid waste generation per capita per day including various biodegradable, non-biodegradable wastes and inert material in the study area in a particular three months period.

From the compiled data, seasonal fluctuations in qualitative and quantitative composition in solid waste generation and segregation in the one year study period were calculated.

Data on solid waste generation and segregation in four seasons of the one year study period were compiled to calculate mean per capita per day values of solid waste segregation and net generation with standard deviations.

\section{Classification of Municipal Waste}

Normally Municipal solid wastes are classified into three categories of biodegradable waste, non-biodegradable waste and inert material.

Biodegradable wastes include paper, plants and animal products which can be degraded by the micro-organisms like bacteria and fungi. These include kitchen waste, waste from fruits, vegetables, meat waste and fish markets etc.

Non-biodegradable wastes are those wastes which can't be degraded by micro-organisms, bacteria and fungi i.e. plastics, glass, x-ray films, celluloid films, batteries, chemicals, radioactive wastes, synthetic, heavy metals etc. The non-biodegradable wastes are most dangerous as they can remain in the environment for decades without being degraded. They are the one of the biggest sources of environmental pollution.

Inert materials include small stems, dust, wax, dirt and hair etc.

\section{E. Segregation of Municipal Solid Waste}

Segregation is the process which helps to segregate reusable, recyclable, biodegradable, non-biodegradable and inert materials from the waste. It reduces the quantity of the waste and if carried out efficiently, it will help to avoid mixing of the different types of waste. Segregation helps in collecting of reusable and recyclable waste from certain municipality waste which may include metal, cardboard, toys, household repairable items, electronic waste etc. The biodegradable and non-biodegradable waste is required to be collected in separate bins or bags of selected colours like green and blue. As per norms, it is required to paste posters and boards in the areas of wards and waste storage with proper guidelines and instructions for segregation of municipality solid waste. Also, there should be enough quantity of bins for collection of waste from household/residential society/ward area. The waste handling staff or ragpickers should be provided with personnel protective equipment i.e. hand gloves, mask, goggles, shoes etc.

\section{OBSERVATION AND ANALYSIS}

\section{A. Solid Waste Generation in Residential Areas}

The study was performed to find out the total generation of solid waste and its management in residential areas of Alwar city. The study has been carried out for a period of thirteen months from May 2018 to May 2019. The waste samples were collected, segregated, weighed and classified according to their components. A questionnaire was also administered to the each household in the different zones of the city which helped in understanding the awareness of the people.

\section{B. Composition of Collected Municipal Solid Waste}

The municipal solid waste is mainly composed of wastes like food waste (including vegetables and fruits), plastics and packaging items, products made of paper, wood materials like card board and chips boards, rubber and textile etc. The table II and graph 1 show the composition of solid waste.

Table II: Composition of Solid Waste in Alwar

\begin{tabular}{|c|l|c|}
\hline S. No. & Constituent & Share (in \%) \\
\hline 1 & Plastics & 5.63 \\
\hline 2 & Food waste & 36.73 \\
\hline 3 & Paper products & 9.82 \\
\hline 4 & Wood & 1.43 \\
\hline 5 & Rubbers & 1.33 \\
\hline 6 & Foliage & 5.70 \\
\hline 7 & Textiles & 2.36 \\
\hline 8 & Other* & 6.98 \\
\hline 9 & Inert Material & 12.63 \\
\hline 10 & Segregated Solid Waste & 17.39 \\
\hline \multicolumn{2}{r|}{ Total } & 100.00 \\
\hline
\end{tabular}

Constituents of Solid Waste Generated in Alwar

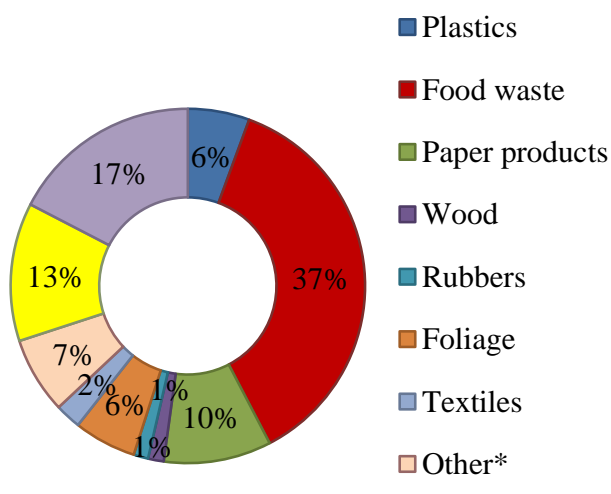

Graph 1: Constituents of Solid Waste in Alwar city C. Seasonal Change in Mean Gross Solid Waste Generation

The different characteristics of MSW in different seasons as well as the yearly average of these characteristics were compared with each zone. The changes in characteristics of MSW with respect to different seasons were found. 
Zone-I: The generation of solid waste per capita per day varied from 0.450 to $0.806 \mathrm{~kg}$ during February- May 2019. The biodegradable and non-biodegradable solid waste per capita per day varied in the range of 0.307 to $0.492 \mathrm{~kg}$ and 0.096 to $0.204 \mathrm{~kg}$ respectively. The maximum mean biodegradable and non-biodegradable solid waste per capita per day were noticed as 0.492 and $0.204 \mathrm{~kg}$ during November-January 2019 respectively and minimum mean biodegradable and non-biodegradable solid waste per capita per day were observed as 0.307 and $0.096 \mathrm{~kg}$ during Feb-May, 2019. The quantities of inert material were found with a maximum of $0.113 \mathrm{~kg}$ during Nov-Jan 2019 and minimum of $0.048 \mathrm{~kg}$ during Feb-May 2019.

Zone-II: The generation of solid waste per capita per day was found out in the range from 0.459 to $0.805 \mathrm{~kg}$ with maximum of $0.805 \mathrm{~kg}$ during May-July 2018 and minimum of $0.459 \mathrm{~kg}$ during Feb-May 2019. The biodegradable and non-biodegradable solid waste per capita per day ranged from 0.317 to $0.543 \mathrm{~kg}$ and 0.072 to $0.154 \mathrm{~kg}$ respectively. The maximum mean biodegradable and non-biodegradable solid waste per capita per day were observed as 0.543 and $0.154 \mathrm{~kg}$ during May-July and Nov-Jan 2019 respectively and minimum mean biodegradable and non-biodegradable solid waste per capita per day were observed as $0.317 \mathrm{~kg}$ during Aug-Oct 2018 and 0.072 kg during Feb-May 2019 respectively. The quantity of inert material was found out with maximum mean of $0.113 \mathrm{~kg}$ during Nov-Jan 2019 and minimum mean of 0.036 during Feb-May 2019.

Zone-III: The generation of solid waste per capita per day was found out in the range from 0.445 to $0.850 \mathrm{~kg}$ with a maximum mean of $0.850 \mathrm{~kg}$ during Nov-Jan 2019 and minimum mean of $0.445 \mathrm{~kg}$ during May-July 2018. The biodegradable and non-biodegradable solid waste per capita per day ranged from 0.296 to $0.526 \mathrm{~kg}$ and 0.105 to $0.209 \mathrm{~kg}$ respectively. The maximum mean biodegradable and non-biodegradable solid waste per capita per day were observed to range between $0.526 \mathrm{~kg}$ to $0.209 \mathrm{~kg}$ during Nov-Jan 2019 respectively and minimum mean biodegradable and non-biodegradable solid waste per capita per day were observed to be 0.296 kg during Feb-May 2019 and $0.105 \mathrm{~kg}$ during Feb-May 2019 respectively. The quantity of inert material was found in the range from 0.044 to $0.115 \mathrm{~kg}$ with maximum mean of $0.115 \mathrm{~kg}$ during Nov-Jan 2019 and minimum mean of 0.044 kg during May-July 2019. Zone IV: The generation of solid waste per capita per day varied in the range of 0.372 to $0.764 \mathrm{~kg}$ with maximum mean of $0.764 \mathrm{~kg}$ during Nov-Jan 2019 and minimum mean of $0.372 \mathrm{~kg}$ during Feb-May 2019. The biodegradable and non-biodegradable solid waste per capita per day ranged from 0.256 to $0.443 \mathrm{~kg}$ and 0.073 to $0.201 \mathrm{~kg}$ respectively. The maximum mean biodegradable and non-biodegradable solid waste per capita per day were observed to be $0.443 \mathrm{~kg}$ and 0.201 during Nov-Jan 2019 respectively and minimum mean biodegradable and non-biodegradable solid waste per capita per day were observed to be $0.256 \mathrm{~kg}$ during Feb-May 2019 and $0.073 \mathrm{~kg}$ during Feb-May 2019 respectively. The quantity of inert material was found in the range from 0.042 to $0.120 \mathrm{~kg}$ with maximum mean of $0.120 \mathrm{~kg}$ during Nov-Jan 2019 and minimum mean of 0.042 kg during Feb-May 2019. The graph 2 shows the seasonal variation in mean gross solid waste generation (kg/capita/day) in Alwar city.

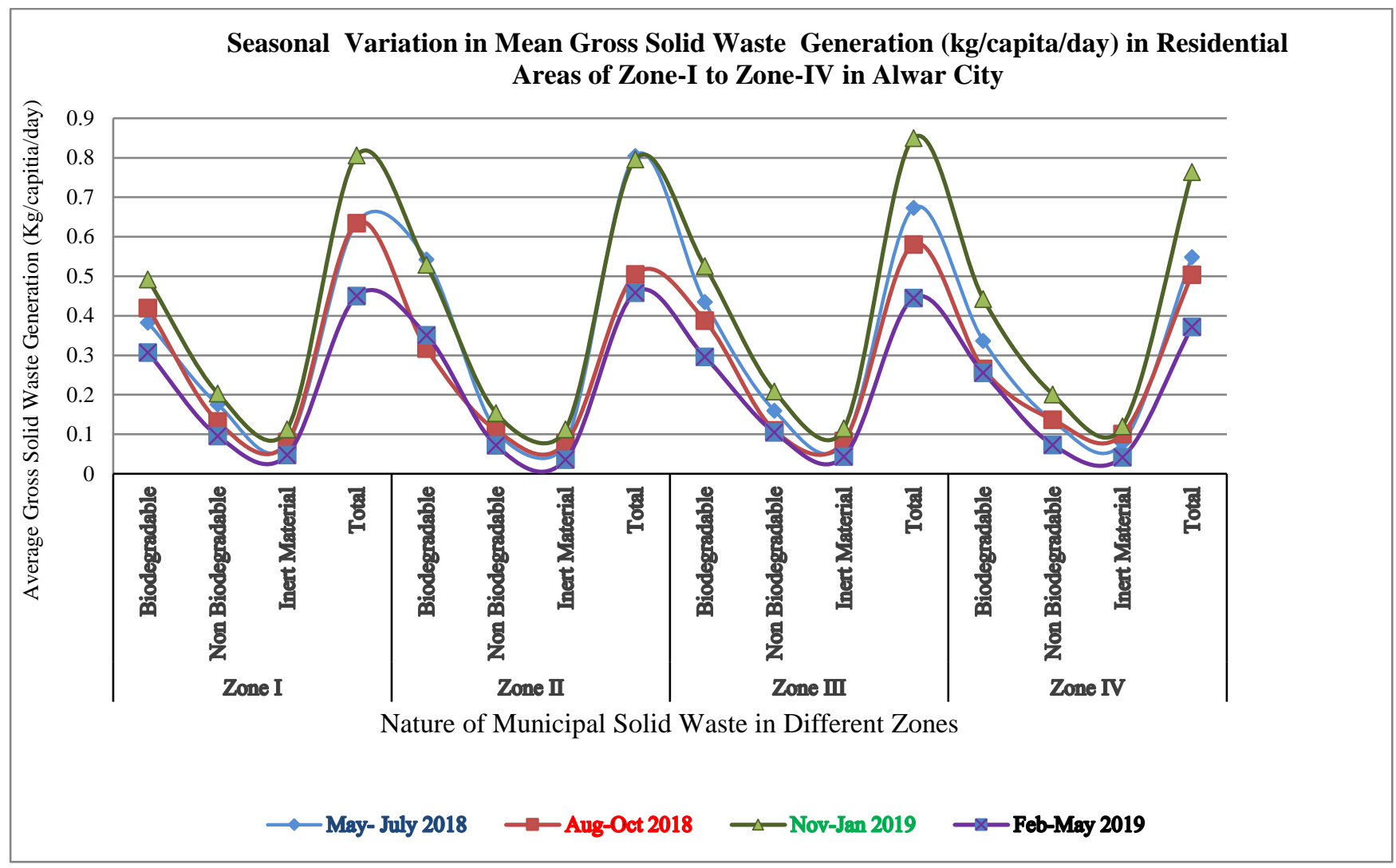

Graph 2: Seasonal Variation in Mean GSW (kg/capita/day) Generation in Residential Areas of Zone-I to Zone-IV in Alwar 


\section{Mean Gross v/s Net Solid Waste Generation}

The gross biodegradable solid waste per capita per day in the residential areas was found in the range from 0.303 to 0.425 $\mathrm{kg}$ with a mean of $0.393 \mathrm{~kg}$ and the gross non-biodegradable solid waste per capita per day ranged from 0.087 to $0.192 \mathrm{~kg}$ with a mean of $0.141 \mathrm{~kg}$. The segregation of recyclable biodegradable waste at source in the residential areas of Alwar city was seen in the range from 0.045 to $0.052 \mathrm{~kg}$ with a mean of $0.051 \mathrm{~kg}$ and segregation of non-biodegradable solid waste per capita per day ranged from 0.034 to $0.063 \mathrm{~kg}$ with a mean of $0.048 \mathrm{~kg}$. After segregating the biodegradable and non-biodegradable wastes at source, the net biodegradable solid waste per capita per day in the residential areas was found out in the range from 0.252 to $0.442 \mathrm{~kg}$ with a mean of $0.343 \mathrm{~kg}$ and net non-biodegradable solid waste per capita per day ranged from 0.052 to $0.129 \mathrm{~kg}$ with a mean of $0.092 \mathrm{~kg}$. The quantities of gross as well as the net generation of the inert material per capita per day were observed to range from 0.043 to $0.115 \mathrm{~kg}$ with a mean of $0.081 \mathrm{~kg}$. The gross solid waste (kg/capita/day) generation in the residential areas of Alwar city was observed with a mean of $0.615 \mathrm{~kg}$. The segregation of the solid waste $(\mathrm{kg} / \mathrm{capita} / \mathrm{day})$ at source was observed with a mean of $0.099 \mathrm{~kg}$. After the segregation of solid waste at source, the net solid waste $(\mathrm{kg} / \mathrm{capita} /$ day) generation was observed with a mean of $0.516 \mathrm{~kg}$. The table III and graph 3 represent the above mentioned statistics in tabular and graphical form.

Table III: Mean Gross and Net Solid Waste Generation (in kg/capita/day) in Alwar City

\begin{tabular}{|ll|c|c|c|c|}
\hline \multicolumn{2}{|c|}{ Solid Waste } & $\begin{array}{c}\text { Biodegradable } \\
\text { (B) }\end{array}$ & $\begin{array}{c}\text { Non } \\
\text { Biodegradable } \\
\text { (NB) }\end{array}$ & $\begin{array}{c}\text { Inert } \\
\text { Material } \\
\text { (IM) }\end{array}$ & $\begin{array}{c}\text { Total }= \\
(\mathrm{B}+\mathrm{NB}+\mathrm{IM})\end{array}$ \\
\hline $\begin{array}{l}\text { Mean Gross Solid Waste (kg/capita/day) } \\
\text { Generated (G) }\end{array}$ & 0.393 & 0.141 & 0.081 & 0.615 \\
\hline $\begin{array}{l}\text { Recyclable Solid Waste (kg/capita/day) } \\
\text { Segregated (r) }\end{array}$ & 0.051 & 0.048 & - & 0.099 \\
\hline $\begin{array}{l}\text { Mean Net Solid Waste (kg/capita/day) Generated } \\
(\mathrm{G}-\mathrm{r})\end{array}$ & 0.343 & 0.092 & 0.081 & 0.516 \\
\hline
\end{tabular}

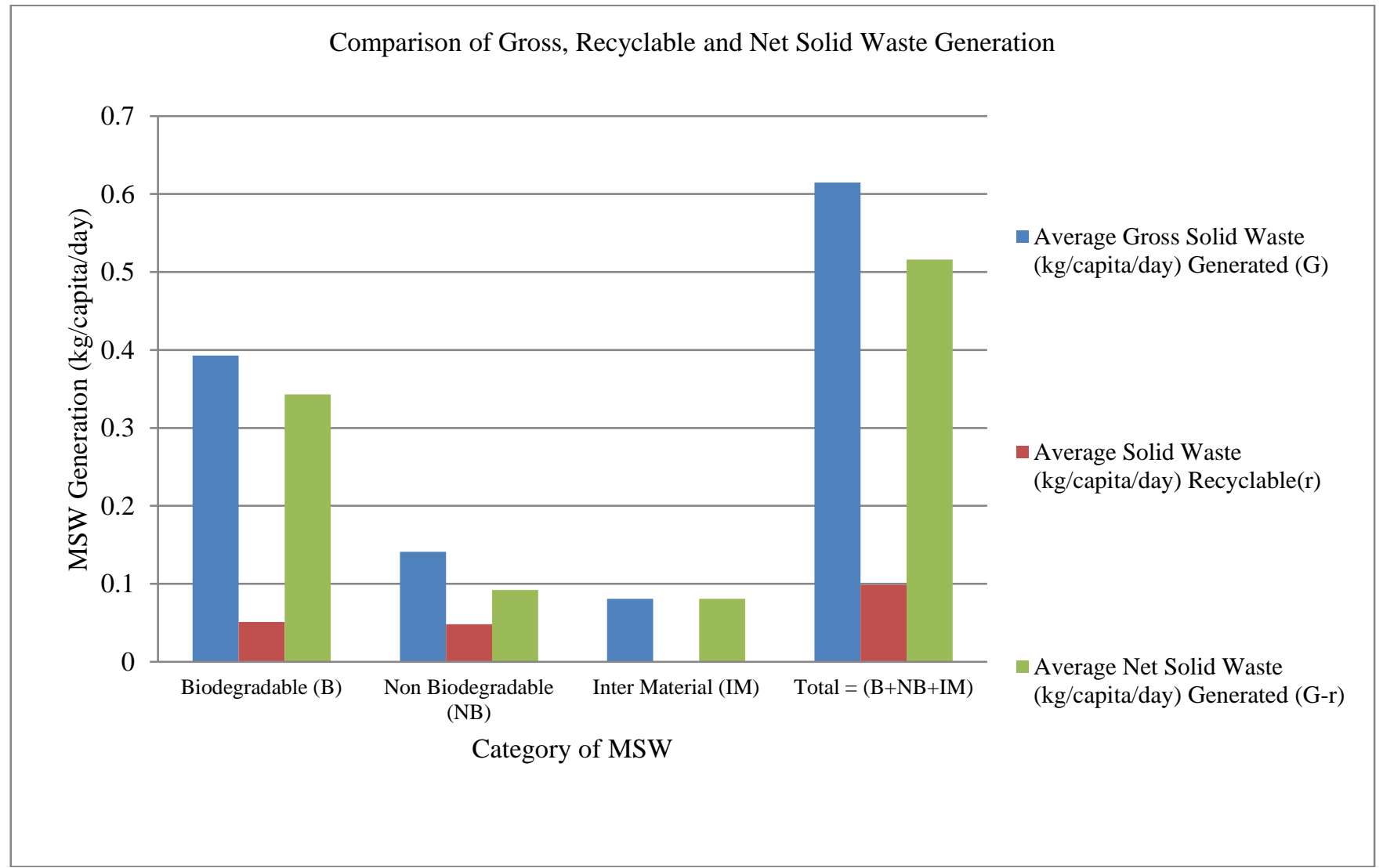

\section{Graph 3: Comparison of Gross, Recyclable and Net Solid Waste Generation in Alwar city}

\section{E. Estimation of MSW Generation in Residential Area}

The study area lies in the municipal corporation limits of Alwar city, whose population was 322,768 as per the 2011 census and assuming an annual growth rate of 3.5\%, the present population is approximately 3.70 lakhs. The total

solid waste collection from the city can be calculated with the help of total population multiplied by the mean waste generation (per capita per day). As shown in table IV below, the net quantity of solid waste generated per day in Alwar city is estimated at 190.92 tonnes. 
Municipal Solid Waste Management Practices in Alwar, Rajasthan, India

Table IV: Total Solid Waste Generation per day in Alwar City

\begin{tabular}{|ll|c|c|c|c|}
\hline \multicolumn{2}{|l|}{ Solid Waste } & $\begin{array}{c}\text { Biodegradable } \\
\text { (B) }\end{array}$ & $\begin{array}{c}\text { Non } \\
\text { Biodegradable } \\
\text { (NB) }\end{array}$ & $\begin{array}{c}\text { Inert Material } \\
\text { (IM) }\end{array}$ & $\begin{array}{c}\text { Total = } \\
\text { (B+NB+IM) }\end{array}$ \\
\hline $\begin{array}{l}\text { Mean Gross Solid Waste (MT/day) } \\
\text { Generated (G) }\end{array}$ & 145.41 & 52.17 & 29.97 & 0.23 \\
\hline $\begin{array}{l}\text { Mean Solid Waste (MT//day) } \\
\text { Recyclable (r) }\end{array}$ & 18.87 & 17.76 & - & 0.04 \\
\hline $\begin{array}{l}\text { Mean Net Solid Waste (MT//day) } \\
\text { Generated (G-r) }\end{array}$ & 126.91 & 34.04 & 29.97 & 190.92 \\
\hline
\end{tabular}

\section{F. Conversion of Solid Waste into Vermi-compost}

Food waste as well as wet food can be used for converting it to vermi-composting. As an estimate, about $36.73 \%$ is the efficiency of conversion. As seen above, the total waste generation in Alwar city is 190.92 tonnes per day, so, vermicompost per day will be approximately 70.12 tpd (tonnes per day).

\section{CONCLUSION}

Based on our observations, it can be concluded that in Alwar city, a total of 190.92 tonnes solid waste is generated per day, out of which 126.91 tonnes is biodegradable solid waste, 34.04 tonnes non-biodegradable solid waste and 29.97 tonnes of inert material. As per the record of municipal corporation Alwar, a total of 185 tonnes of solid waste is disposed off per day in dumping site by method of open dumping and bio-medical waste is also dumped along with the municipal waste, which is a very serious health hazard. Bio-medical waste needs to be collected and treated separately. Secondly, there is a great potential of converting biodegradable solid waste into vermi-compost or energy. It is suggested to give utmost attention towards management of municipal solid waste in the city because at present, there is no scientific method adopted during the handling of solid waste. It was observed that neither the collection of solid waste is proper nor the segregation is performed before disposal. The concerned authorities need to monitor the whole process and take necessary steps to streamline it so that solid waste can be converted into a useful resource.

\section{ACKNOWLEDGMENT}

The authors are thankful to the authorities at municipal corporation Alwar for providing all necessary support to carry out the research successfully.

\section{REFERENCES}

1. Compendium of Environment Statistics, Department of Statistics, Ministry of Planning and Programme Implementation Government of India, New Delhi, 1998.

2. Solid Waste Management Rules, Ministry of Environment, Forest and Climate Change, Govt. of India, 2016

3. Abbasi, M and E.V. Ramasamy, "Solid Waste Management with earthworms". Discovery Publishing House, New Delhi, 2002.

4. Adhikari, B.K. Barrington and J. Martinen, "Urban food waste generation challenges and opportunities in metro cities". International Journal of Environmental Waste Management, 3 (1/2): 4-21, 2010.

5. Agrawal, G., "Medical waste disposal in urban cities in India". Span, Nov/Dec: 22-26, 2001.

6. C. Palanichamy and C. Nadarajan, "Municipal solid waste fuelled power generation in India”, Energy Conversion, IEEE Transactions. 18: 556-563, 2002.

7. Schafer, B.M., "Disposing of the Municipal Solid Waste by pyrolysis process", Environmental Science \& Technology, 9(2): 71-78, 1976.
8. Central Electricity Regulatory Commission (CERC). Tariff. available at http://www.cerc.gov.in/tariff.html, April 2016.

9. C. Cheung and K. Bengtson, "Development of a renewable hybrid power generation system", Systems and Information Engineering Design Symposium. 55-60, 2010.

10. Khandelwal, K.C., "Harnessing wealth from wastes: an overview. Indian Renewable Energy Development Agency (IREDA), 8 (1): 5-8, 1996.

11. Rao, G.K., "Recycle and Reuse of Municipal Solid Waste: An Economic proposition for a developing Nation India", Journal of Environmental Protection, 8(1): 57-59, 1998.

\section{AUTHORS PROFILE}

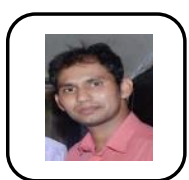

Arun Kumar Yadav, is a Post Graduate Scholar in Environmental Engineering at the Department of Civil Engineering, Rajasthan Technical University, Kota. He passed out his B. Tech. in Mechanical Engineering from MJRP College of Engineering \& Technology, Jaipur; affiliated to Rajasthan Technical University, Kota in 2012 and Diploma in Mechanical Engineering from Govt. Polytechnic College Jodhpur in 2008.

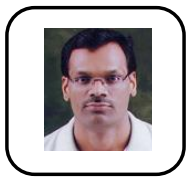

Dr. Mahendra Pratap Choudhary, is an Associate Professor in the Department of Civil Engineering at Rajasthan Technical University, Kota since August 2013. He completed his Master of Engineering (Environmental) and $\mathrm{PhD}$ in Civil Engineering from M. B. M. Engineering College, Jai Narain Vyas University, Jodhpur in 2006. Dr. Choudhary had served as Assistant Engineer in the Public Health Engineering Department, Govt. of Rajasthan for more than 15 years. 